\title{
Mesothelioma in a community in the north of England
}

\author{
A T Edward, D Whitaker, K Browne, F D Pooley, A R Gibbs
}

\begin{abstract}
Objectives-To find the numbers of mesotheliomas in Calderdale over the period 1966-94 and determine their relation to asbestos exposure, pathology, and mineral fibre burden within the lungs of affected subjects.

Methods-Cases were entered into the study if the subject had been diagnosed with mesothelioma after postmortem and histopathological examinations. Occupational data were obtained mainly from the case records of the Cape Asbestos medical officer, hospital, and medical practitioner and from death certificates. Analyses of the mineral fibres were performed with transmission electron microscopy and energy dispersive $x$ ray spectometry.
\end{abstract}

Results-73 mesotheliomas were diagnosed from 1966 to 1994 . Forty four were associated with exposure at the Acre Mill factory, which manufactured asbestos products. Concentrations of amphibole asbestos fibres were found to be raised above controls in 31 out of 32 cases associated with Acre Mill exposure, in 10 out of 12 other cases exposed to asbestos and eight out of 17 cases not exposed to asbestos.

Conclusions-There was a high number of mesotheliomas in Calderdale. More than half of the cases were associated with occupation at the Acre Mill factory and were associated with exposure to amphibole asbestos, predominantly crocidolite. No cases associated with neighbourhood exposure to asbestos were identified.

(Occup Environ Med 1996;53:547-552)

Keywords: asbestos; mesothelioma

Calderdale is a semi-rural community of 192000 in the north of England with a high incidence of malignant mesothelioma. The area included the Acre Mill factory, originally a 19th century cotton mill, but which was commandeered by the Home Office in 1939 to produce gas mask filters.

In 1940 the manufacturing processes and range of products were increased. All forms of commercial asbestos were used at the factory-chrysotile of Canadian or Rhodesian origin from 1942 to 1970; amosite from South Africa from 1949 to 1970 ; crocidolite through- out the life of the factory. From 1939 to 1947 crocidolite was the main fibre used. From 1949 about one third of the production employees worked in the textile department, which was then wholly chrysotile; from 1953 crocidolite textile manufacture was transferred to Acre Mill, and over half the workers were employed in this department, with one third of production being crocidolite textiles. The main use of crocidolite was in the manufacture of filters in 1940-4 and in textile production 1952-66. Production of amosite insulation occupied about one quarter of the production employees during this period. Manufacture of textiles ended in 1966; for the four remaining years the main fibre used was amosite. Manufactured products included millboard, pipe lagging, steam engine insulation jackets, textiles, and gas mask filters. Industrial processes included unloading of hessian bags containing asbestos (replaced in the 1960s by impermeable bags), sorting, carding, spinning, winding and weaving of the mineral and general cleaning and disposal of waste asbestos. The factory closed in 1970 and has since been demolished.

Although the mill has gone, there remains a legacy of asbestos related disease and although there has been some reference to problems resulting from this exposure, ${ }^{12}$ there has been no detailed study of the occurrence of mesothelioma in Calderdale.

The purpose of the present study, which covers a period of almost 28 years from 1966 , when the first case of malignant mesothelioma was diagnosed, was to find the number of mesotheliomas and determine their relation to asbestos exposure, pathology, and mineral fibre burden within the lungs of affected subjects.

\section{Material and methods}

A rigorous search was undertaken to identify all cases of mesothelioma from sources of information including Cape Asbestos records, patient records from the major medical practice in the Hebden Bridge area, Calderdale death certificates, and the pathology files of the Halifax area hospitals. Cases were entered into the study if the case had been diagnosed as mesothelioma after postmortem and histopathological examinations. Necropsies on subjects with known or suspected asbestos related disease were performed at the Royal Halifax Infirmary. Information about the mesothelioma cases was gleaned from the Cape Asbestos medical officer, hospital, and 
medical practitioner case records, as well as from death certificates. Further information was available from former employees of Acre Mill and relatives of the deceased. As might be expected, exact employment details during the war period were unsatisfactory but good employment records of the postwar operation were made available through the courtesy of Cape Industries.

The survey also included a few people who were past employees at Acre Mill, but who had died outside the area. In these cases the reporting pathologists were contacted wherever possible and the histopathogical material reviewed. A review was also conducted of all cases certified as carcinoma of the lung and known to be exposed to asbestos in case some were misdiagnosed mesotheliomas.

Age, sex, address, work history, and employment details were recorded. All available cytological and necropsy material was reviewed and, where appropriate, additional stains were performed. The postmortem data included tumour site, histological pattern, and distribution of metastases.

An analysis of electron microscopic fibre burden was performed on 61 cases. Tissue samples were divided into two; one half was dried at $80^{\circ} \mathrm{C}$ to constant weight and the wet to dry weight calculated. The other half was digested in $40 \%$ potassium hydroxide, washed, and then ashed at $350^{\circ} \mathrm{C}$ for three hours in an atmosphere of oxygen. The final abstract was suspended in distilled water and aliquots of known volume were filtered onto nucleopore filters. These were carbon coated, the filters were dissolved in chloroform, and the carbon films were mounted on to gold electron microscope support grids for transmission electron microscopy. On average 100 to 200 fibres a case were counted and typed by an energy dispersive $x$ ray analysis technique. $^{3}$

\section{Results}

A total of 73 mesotheliomas were identified in the period 1966-94, which gives an average incidence over the period of about $12.5 / \mathrm{mil}$ lion persons/year. This was estimated from the population statistics for Calderdale over the period and assuming that all the mesothelioma cases would have been picked up from the sources already detailed. It is probable that case identification might not have been complete. Fifty six were in men and 17 were in women. Forty four of the cases were associated with Acre Mill, 12 had a history of other exposure to asbestos but in 17 no history of significant exposure to asbestos could be established, nor did they live within two miles of the Acre Mill factory.

The first case of mesothelioma was identified in 1966 in an Acre Mill worker.

The figure shows the number of mesotheliomas by year. Table 1 shows the age at death of the mesothelioma cases; the youngest was aged 39 years but the mean was 62.3 for the Acre Mill group, 69.7 years for the group with other history of exposure, and $61 \cdot 1$ for the group with no history of exposure

Of the various jobs at Acre Mill predisposing to mesothelioma, work in the textile department (spinning, weaving, and carding) accounted for most cases. But workers not directly involved in manufacturing (plumber, maintenance engineer, office worker) were also at risk.

Most of the women (13 out of 17) were associated with Acre Mill and included two aged 47 and 61 who had exposure from their fathers' dusty clothes (paraoccupational).

Asbestos exposure in the group with other history of exposure to asbestos was varied and included working in other asbestos factories (four), boiler making or lagging (five), joinery making fireproof doors (one), plumbing (one), and a laboratory assistant (one).
Number of mesotheliomas a year from 1966 to 1994 in each group.

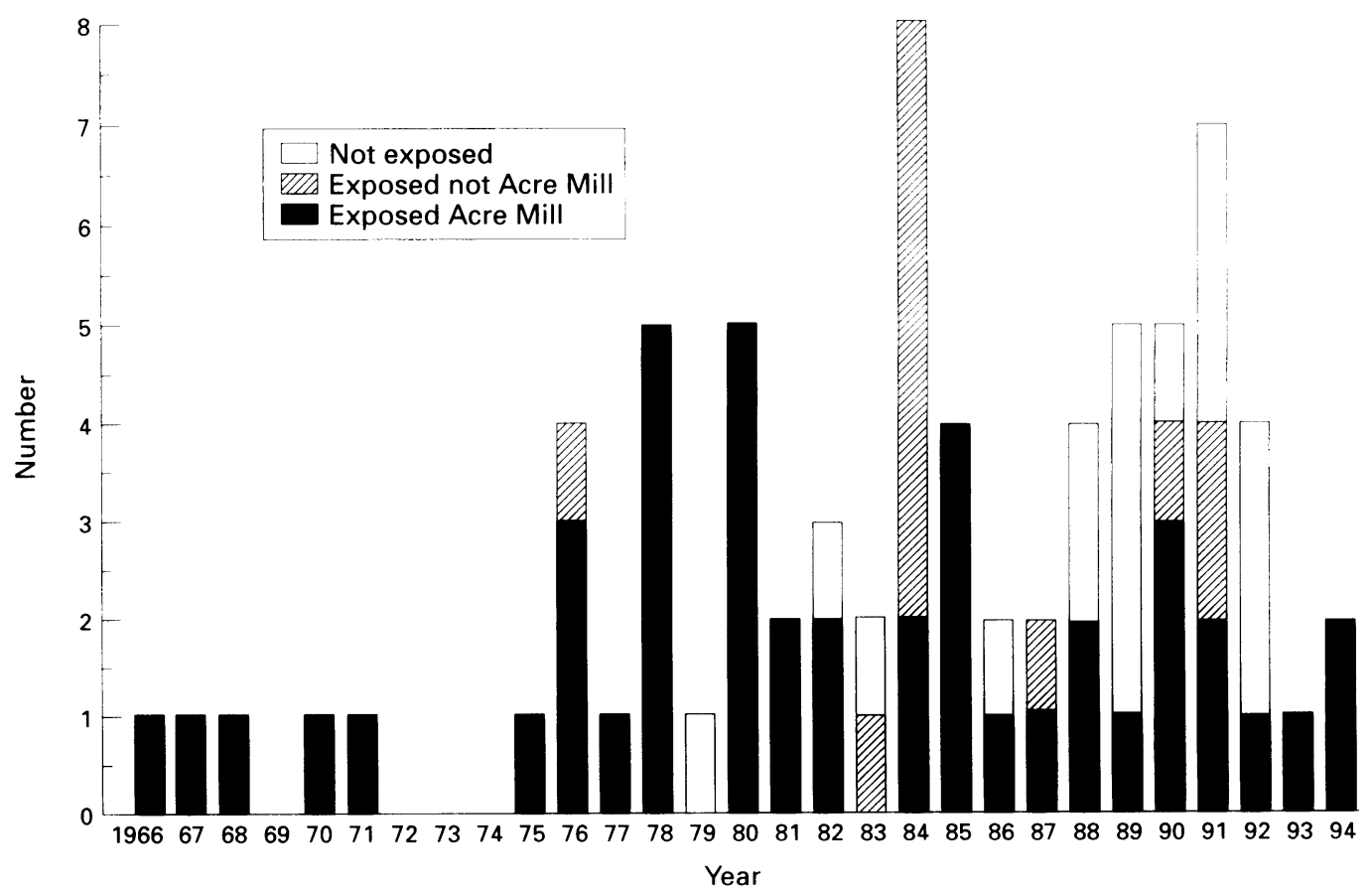

Year 
Table 1 Age, sex, latency, and fibre concentrations (millions/g dry lung) for each case

\begin{tabular}{|c|c|c|c|c|c|c|c|c|}
\hline Case & Age & Sex & Exposure & Latency & Total & Crocidolite & Amosite & Chrysotile \\
\hline 1 & 55 & F & $\mathrm{AM}$ & 37 & $11 \cdot 3$ & 1.6 & 1.6 & 4.5 \\
\hline $\begin{array}{l}2 \\
3\end{array}$ & 72 & M & AM & 28 & $\overrightarrow{414}$ & $\overline{139.5}$ & $\overline{07}$ & $\overline{327}$ \\
\hline $\begin{array}{l}3 \\
4\end{array}$ & 56 & M & $\mathrm{AM}$ & 32 & $\begin{array}{r}414 \\
1275\end{array}$ & 139.5 & 207 & $23 \cdot 7$ \\
\hline $\begin{array}{l}4 \\
5\end{array}$ & 59 & M & $\mathrm{AM}$ & 19 & 1275 & 841 & ND & 51 \\
\hline $\begin{array}{l}5 \\
6\end{array}$ & 48 & M & $\mathrm{AM}$ & 22 & 39 & $9 \cdot 3$ & 3.3 & ND \\
\hline $\begin{array}{l}6 \\
7\end{array}$ & 50 & M & $\mathrm{AM}$ & 21 & - & - & $\bar{\pi}$ & 0 \\
\hline $\begin{array}{l}7 \\
8\end{array}$ & 51 & $\mathbf{M}$ & $\mathrm{AM}$ & 28 & 90 & 51 & ND & 22 \\
\hline & 51 & $\mathbf{M}$ & $\mathrm{AM}$ & 28 & $\overline{7}$ & & & - \\
\hline $\begin{array}{r}9 \\
10\end{array}$ & 73 & M & AM & 30 & 8270 & 7195 & 744 & 82 \\
\hline 11 & 40 & M & AM & 24 & $\overline{2573}$ & $\overline{70}$ & 1767 & $\overline{18}$ \\
\hline 12 & $\begin{array}{l}52 \\
48\end{array}$ & $\begin{array}{l}\mathbf{M} \\
\mathbf{M}\end{array}$ & $\begin{array}{l}\mathrm{AM} \\
\mathrm{AM}\end{array}$ & $\begin{array}{l}29 \\
12\end{array}$ & $\begin{array}{l}2573 \\
1350\end{array}$ & $\begin{array}{l}748.8 \\
959\end{array}$ & $\begin{array}{r}1767 \\
81\end{array}$ & $\begin{array}{r}18 \\
243\end{array}$ \\
\hline 13 & $\begin{array}{l}40 \\
75\end{array}$ & $\mathbf{M}$ & $\mathrm{AM}$ & 36 & 1102 & 1014 & $\begin{array}{l}81 \\
22\end{array}$ & $\begin{array}{r}443 \\
44\end{array}$ \\
\hline 14 & 71 & M & $\mathrm{AM}$ & 31 & $41 \cdot 2$ & $4 \cdot 7$ & $26 \cdot 4$ & $2 \cdot 3$ \\
\hline $\begin{array}{l}15 \\
16\end{array}$ & 70 & M & $\mathrm{AM}$ & 18 & $62 \cdot 2$ & $33 \cdot 3$ & $4 \cdot 4$ & 6.7 \\
\hline $\begin{array}{l}16 \\
17\end{array}$ & 49 & M & $\mathrm{AM}$ & 27 & 315 & 309 & $4 \cdot 4$ & 1.6 \\
\hline 17 & 47 & $\mathbf{M}$ & AM & 32 & 52 & $4 \cdot 3$ & 1 & ND \\
\hline & 48 & $\mathrm{~F}$ & AM & 31 & - & - & - & - \\
\hline $\begin{array}{l}19 \\
20\end{array}$ & 78 & $\mathbf{M}$ & AM & 37 & - & - & - & - \\
\hline $\begin{array}{l}20 \\
21\end{array}$ & 43 & $\mathbf{F}$ & $\mathrm{AM}$ & 26 & - & - & - & - \\
\hline $\begin{array}{l}21 \\
22\end{array}$ & 76 & M & $\mathrm{AM}$ & 26 & $42 \cdot 4$ & $25 \cdot 6$ & ND & ND \\
\hline $\begin{array}{l}22 \\
23\end{array}$ & 62 & $\mathbf{M}$ & AM & 35 & & - & - & - \\
\hline $\begin{array}{l}23 \\
24\end{array}$ & 51 & M & $\mathrm{AM}$ & 36 & 4518 & 4478 & ND & ND \\
\hline $\begin{array}{l}24 \\
25\end{array}$ & 59 & M & $\mathrm{AM}$ & 43 & $45 \cdot 3$ & $24 \cdot 1$ & 0.4 & ND \\
\hline $\begin{array}{l}25 \\
26\end{array}$ & 63 & $\mathrm{~F}$ & $\mathrm{AM}$ & 36 & $=$ & - & - & - \\
\hline $\begin{array}{l}26 \\
27\end{array}$ & $\begin{array}{l}69 \\
80\end{array}$ & $\begin{array}{l}\mathrm{M} \\
\mathrm{F}\end{array}$ & AM & $\begin{array}{l}27 \\
40\end{array}$ & $84 \overline{14}$ & $\mathrm{ND}$ & $84 \overline{14}$ & $N \bar{D}$ \\
\hline 28 & 67 & $\mathrm{~F}$ & $\begin{array}{l}\text { AM } \\
\text { AM }\end{array}$ & $\begin{array}{l}40 \\
16\end{array}$ & $\begin{array}{r}626 \\
\end{array}$ & 569 & $\begin{array}{l}0414 \\
11 \cdot 3\end{array}$ & $\begin{array}{r}\text { ND } \\
23\end{array}$ \\
\hline 29 & 77 & M & $\mathrm{AM}$ & 29 & - & - & & \\
\hline 30 & 74 & $\mathbf{F}$ & AM & 33 & 322 & 19 & 287 & 2.9 \\
\hline $\begin{array}{l}31 \\
32\end{array}$ & 56 & $\mathbf{F}$ & $\mathrm{AM}$ & 40 & 5982 & 5982 & ND & ND \\
\hline $\begin{array}{l}32 \\
33\end{array}$ & 69 & $\mathbf{F}$ & AM & 40 & $179 \cdot 8$ & 1.8 & 145.6 & 10.8 \\
\hline $\begin{array}{l}33 \\
34\end{array}$ & 63 & F & AM & 36 & $\overline{-1}$ & חור & $\overline{0}_{0}$ & $\overline{1}$ \\
\hline $\begin{array}{l}34 \\
35\end{array}$ & 61 & $\mathrm{~F}$ & $\mathrm{AM}$ & - & $21 \cdot 9$ & ND & 0.2 & $15 \cdot 4$ \\
\hline 35 & 62 & $\mathbf{M}$ & AM & 27 & 323 & 148.6 & 109.8 & $9 \cdot 7$ \\
\hline $\begin{array}{l}36 \\
37\end{array}$ & 77 & M & $\mathrm{AM}$ & 24 & 169 & 157.2 & $6 \cdot 8$ & $3 \cdot 3$ \\
\hline 37 & 77 & M & $\mathrm{AM}$ & 30 & 469 & 313 & 83 & 10 \\
\hline 38 & 80 & M & AM & 40 & 272.9 & 237.4 & $13 \cdot 6$ & ND \\
\hline 39 & 68 & $M$ & AM & 40 & ND & ND & $240 \cdot 2$ & ND \\
\hline 40 & 72 & $\mathbf{F}$ & AM & 51 & $362 \cdot 3$ & $30 \cdot 2$ & 313.5 & $17 \cdot 1$ \\
\hline 41 & 61 & $\mathbf{M}$ & AM & 38 & 247.5 & 227.6 & 2.5 & 2.5 \\
\hline 42 & 62 & F & $\mathrm{AM}$ & 45 & 1498.8 & 1369.9 & 15 & 15 \\
\hline 72 & 63 & $\mathbf{M}$ & $\mathrm{AM}$ & 44 & $532 \cdot 1$ & $335 \cdot 2$ & 165 & $5 \cdot 3$ \\
\hline 73 & 58 & M & $\mathrm{AM}$ & 26 & $54 \cdot 7$ & ND & $21 \cdot 4$ & ND \\
\hline 43 & 78 & $\mathbf{M}$ & 0 & 44 & $70 \cdot 2$ & 13.3 & 0.7 & $10 \cdot 6$ \\
\hline 44 & 71 & M & O & $>30$ & 22 & 2.8 & ND & $4 \cdot 4$ \\
\hline 45 & 67 & $\mathbf{M}$ & O & $>30$ & 447.5 & 385 & 71.6 & 4.5 \\
\hline 46 & 61 & $\mathbf{M}$ & O & 42 & 18.6 & 0.8 & ND & $4 \cdot 1$ \\
\hline 47 & 73 & $\mathbf{M}$ & O & - & $22 \cdot 6$ & ND & 5.4 & 4.5 \\
\hline 48 & 72 & $\mathrm{~F}$ & $\mathbf{O}$ & - & 79.6 & $2 \cdot 4$ & ND & ND \\
\hline 49 & 61 & $\mathbf{M}$ & O & - & 72.5 & ND & 5.8 & 5.8 \\
\hline 50 & 63 & $\mathbf{M}$ & O & 44 & 51.1 & 18 & ND & $9 \cdot 7$ \\
\hline 51 & 79 & $\mathbf{M}$ & O & - & 60.4 & 3.7 & 5.3 & 9 \\
\hline 52 & 76 & $\mathbf{M}$ & O & $>40$ & 121.5 & $2 \cdot 3$ & $2 \cdot 3$ & 20.8 \\
\hline 53 & 60 & $\mathbf{M}$ & 0 & $>30$ & 4.9 & 0.4 & 0.8 & 1.5 \\
\hline 54 & 75 & $\mathbf{F}$ & 0 & 50 & 11.8 & $1 \cdot 1$ & ND & 0.6 \\
\hline 55 & 70 & $\mathbf{M}$ & NH & - & 282.9 & ND & ND & $28 \cdot 3$ \\
\hline 56 & 59 & $\mathrm{M}$ & NH & - & 28.6 & ND & $1 \cdot 2$ & 7.7 \\
\hline 57 & 86 & $\mathbf{M}$ & NH & - & 16.8 & ND & 0.3 & $11 \cdot 6$ \\
\hline 58 & 69 & $\mathbf{M}$ & NH & - & 8.5 & ND & ND & 1.9 \\
\hline $\begin{array}{l}30 \\
59\end{array}$ & 55 & $\mathrm{~F}$ & NH & - & $7 \cdot 1$ & ND & $0 \cdot 1$ & 0.4 \\
\hline 60 & 60 & $\mathbf{M}$ & $\mathrm{NH}$ & - & 55.8 & ND & 0.6 & 18 \\
\hline 61 & 51 & $\mathrm{~F}$ & $\mathrm{NH}$ & - & $5 \cdot 1$ & 0.1 & 0.2 & ND \\
\hline 62 & 55 & $\mathbf{M}$ & NH & - & 35.9 & ND & 1.8 & 27.9 \\
\hline 63 & 63 & $\mathbf{M}$ & NH & - & 92.8 & 15 & ND & 1.7 \\
\hline 64 & 39 & $\mathbf{M}$ & NH & - & 12.5 & $2 \cdot 2$ & 0.1 & 1 \\
\hline 65 & 47 & $\mathbf{M}$ & NH & - & $68 \cdot 2$ & $4 \cdot 8$ & ND & 40.9 \\
\hline 66 & 83 & $\mathbf{M}$ & NH & - & $32 \cdot 2$ & 0.8 & ND & $1 \cdot 2$ \\
\hline 67 & 70 & M & NH & - & - & $5 \cdot 3$ & ND & 6 \\
\hline 68 & 59 & $\mathbf{M}$ & $\mathrm{NH}$ & - & $34 \cdot 6$ & 1 & 0.7 & 0.5 \\
\hline 69 & 47 & $\mathbf{M}$ & $\mathrm{NH}$ & - & - & ND & 0.15 & 0.1 \\
\hline 70 & 57 & $\mathbf{M}$ & $\mathrm{NH}$ & - & $34 \cdot 3$ & 1.4 & $1 \cdot 7$ & 0.3 \\
\hline 71 & 68 & $\mathbf{M}$ & $\mathrm{NH}$ & - & - & ND & 0.6 & 0.6 \\
\hline
\end{tabular}

AM = Acre Mill; $\mathrm{O}=$ exposed at site other than Acre Mill; $\mathrm{NH}=$ no history of exposure; ND = not detected; Total = all fibres both asbestos and non-asbestos.

Reliable data on the period of exposure could only be obtained in the Acre Mill group. This ranged from two months to 30 years with a mean of 6.6 years. In all cases with $<6$ months exposure (four), the employees had worked in the textile department and of the three cases subjected to mineral analyses all had substantially raised crocidolite concentrations $25 \cdot 6,33.3$, and 51.0 million fibres $/ g$ dried lung. Only 15 of the 43 Acre Mill employees who died of mesothelioma had worked there for over five years.

The latent period between first exposure to asbestos and death ranged from 12 to 44 (mean 31.4) years for the Acre Mill group (table 1). The subject with the shortest latency period had worked as a carder and spinner for 11 years between 1956 and 1967 and died of a mesothelioma in 1968 at the age of 48 years. Mineral analysis showed substantially raised crocidolite (959 million) and amosite (81.0 million) fibres/g of dried lung.

\section{PATHOLOGY}

Sixty two out of 73 mesotheliomas were pleural in origin-36 from the right, 23 from the left, and three bilateral. There were 11 peritoneal mesotheliomas all occurring in the 
Acre Mill group. The histopathology of all but two cases was known and reviewed. Twenty seven were epithelial, 30 were biphasic, and 14 were sarcomatous. There was no difference in the distribution of tumour types between the Acre Mill and other groups, nor was there a difference between pleural and peritoneal mesotheliomas. Five cases included in this study were originally diagnosed as adenocarcinomas but were reclassified as mesotheliomas after full review with supplemental stains and immunohistochemistry.

MINERAL ANALYSIS

Table 2 gives the ranges, median, and mean concentrations for amosite, crocidolite, and chrysotile asbestos in the lung tissues for each of the three groups. Tremolite asbestos was detected in only three cases-2.0,5.3, and 21.9 million fibres/g of dried lung and these were from Acre Mill. Concentrations of amphibole were considered to be raised in 31 out of 32 cases at Acre Mill ( $>1$ million crocidolite fibres/g of dry tissue in 29 and $>1$ million amosite fibres/g dry tissue in 24), 10 out of 12 other cases exposed to asbestos ( $>1 \mathrm{mil}-$ lion crocidolite fibres $/ \mathrm{g}$ in eight and $>1 \mathrm{mil}-$ lion amosite fibres/g in five), and eight out of 17 cases without exposure ( $>1$ million crocidolite fibres/g in five and $>1$ million amosite fibres/g in three). Chrysotile asbestos was considered to be increased in only three cases, all from Acre Mill, and was associated with increased amphibole concentrations. One of the two mesothelioma cases associated with the paraoccupational exposures at Acre Mill had an amphibole concentration of 0.2 million fibres of amosite which was considered not to be increased above background. The other had a significantly raised amphibole concentration of 4.3 million fibres of crocidolite and 1 million fibres of amosite. There was a positive correlation between the period of exposure worked at Acre Mill and amphibole asbestos ( $R 0.49, P=0.005$ ), but a negligible correlation with the chrysotile asbestos fibre burden within the lungs ( $R 0.34, P=0.06)$.

Ten out of the 11 peritoneal mesotheliomas had mineral analysis and all showed raised amphibole concentrations. Crocidolite varied from 1.8 to 7195 (mean 2011.8, median $542.0)$ and the amosite from undetectable to 1767 million fibres (mean 316.2, median $83.8) / g$ of dried lung. Nine of the cases

Table 2 Results of mineral analysis for each group (millions of fibres/g dried lung)

\begin{tabular}{llcrc}
\hline & Minimum & Maximum & Mean & Median \\
\hline Acre Mill group (32 cases): & ND (3) & 7195.0 & 789.3 & 144.0 \\
$\quad$ Crocidolite & ND (5) & 8414.0 & 396.6 & 14.3 \\
Amosite & ND (9) & 243.0 & 19.2 & 4.9 \\
Chrysotile & ND (2) & 358.0 & 33.6 & 2.35 \\
Other exposure group (12 cases): & ND (5) & 71.6 & 7.7 & 0.75 \\
Crocidolite & ND (1) & 20.8 & 6.3 & 4.5 \\
Amosite & Chrysotile & 5.3 & 1.8 & ND \\
Non-exposure group (17 cases): & ND (9) & 1.8 & 0.4 & 0.15 \\
Crocidolite & ND (1) & 40.9 & $\mathbf{8 . 7}$ & 1.7 \\
Amosite & & & \\
\hline
\end{tabular}

$\mathrm{ND}()=$ number of cases in which no asbestos fibre of that type was detected. showed combined amphibole concentrations of $>100$ million fibres/g of dried lung.

\section{Discussion}

Not surprisingly more than half the mesothelioma cases were associated with occupation at Acre Mill. Over the 30 year period of its operation between 2000 and 3000 people worked at the factory. During the war years the number of production employees averaged between 100 and 200; numbers then increased to a peak of about 250 during the 1950 s, declining again to the earlier level during the 1960 s. The mill was a major employer of local labour with a reputation for its good wages, and social and welfare facilities. In common with many asbestos factories, working conditions in respect of asbestos dust were poor, especially in the early years of its operation. Counts of airborne asbestos fibres within the factory were fragmentary and uncertain but suggest that the concentrations were in the region of 5 to $10 \mathrm{fibres} / \mathrm{ml}$ in the amosite production areas, and about $10 \mathrm{fibres} / \mathrm{ml}$ in the textile areas during the 1950 s falling to below 5 fibres/ml in the 1960s. His Majesty's Inspector of Factories ${ }^{2}$ gave several adverse reports and in 1967 these warnings included the comment that "the recently recorded case of mesothelioma may be the first of many in the Hebden Bridge area". This statement was prophetic and Acre Mill is one of the so called "hot spots" for mesothelioma in the United Kingdom. ${ }^{4}$

Unfortunately we do not have control ranges for the various asbestos fibre types in the lung tissues of subjects without asbestos related diseases and without a history of asbestos exposure living in the Calderdale area. However, previous studies of controls taken from several different areas in different countries, including rural ones, have shown a crocidolite range and an amosite range from undetectable to 1 million fibres $/ g$, and a chrysotile range from undetectable to $50 \mathrm{mil}-$ lion fibres/g. ${ }^{5-8}$ Therefore, we have taken these upper concentrations to be the cut offs for background.

All the main commercial forms of asbestos were used at Acre Mill. Crocidolite was used throughout its period of operation; initially in preparation of gas mask filters and later in textiles. Crocidolite is regarded as the most potent form for causing mesothelioma and it was found in significant quantities in the lungs of 28 out of the 31 Acre Mill cases analysed. Even in those cases employed for $<6$ months there were crocidolite concentrations ranging from 25.6 to 51.0 million fibres $/ g$ of dried lung. It is the likely cause of the very high incidence of mesothelioma at this factory. This is comparable with the experience of workers in the Nottingham gas mask factory who were exposed to filters containing crocidolite ${ }^{9}$ which were made at Acre Mill and the Barking factory of Cape Industries, and in the lung tissues of whom increased concentrations of crocidolite were found.

In only two cases at Acre Mill were there 
raised amosite concentrations (8414 and 240 million fibres/g of dried lung) and no crocidolite fibres detected. These subjects were employed in the sectional department which was involved in the production of pipe sections and slabs containing amosite. Chrysotile concentrations were increased in three cases, all from Acre Mill, but they were accompanied by raised crocidolite or amosite concentrations. These findings support previous studies which have shown that amphiboles have a much greater potential for causing mesothelioma than chrysotile. ${ }^{10}$

In the other group exposed to asbestos eight out of 12 cases had increased crocidolite concentrations, five had raised amosite concentrations, and none had raised chrysotile concentrations, but two of the cases had normal asbestos fibre concentrations by mineral analysis.

In the group not exposed to asbestos, eight out of 17 cases showed raised concentrations of crocidolite or amosite fibre, but in the remaining nine cases the fibre concentrations were normal. This supports other studies which have indicated that some mesotheliomas are unrelated to asbestos exposure. ${ }^{11}$

Reliable data for the duration of time subjects were exposed to asbestos could be obtained only for the Acre Mill group and this ranged from two months to 30 years. In two instances the employment period was for two months only, both in the textile department and both had substantial amounts of crocidolite within the lungs ( 33.3 and 25.6 million fibres/g dried lung), thus confirming the dusty working conditions. All five cases of mesothelioma with exposures of $<6$ months had worked in the textile department. Only 17 of the Acre Mill group had worked there for $\geqslant$ five years. There was a stronger correlation between the amphibole than the chrysotile asbestos fibre concentrations in the lung tissues and the period of exposure for both the mesothelioma cases and other subjects employed at Acre Mill. It is well established by animal and human studies that chrysotile is much more efficiently cleared from the lung than amphibole asbestos. ${ }^{12-14}$ This is one of the main reasons, taking into account doses, why amphiboles are much more pathogenic in causing mesothelioma than chrysotile.

It is not possible to predict whether the number of mesotheliomas resulting from the Acre Mill exposure is in decline but the trend would suggest at least a plateau by 1990 . The greatest number of mesotheliomas a year occurred in the 1970s and early 1980s. However, crocidolite was used at the mill up until its closure in 1970 and given that the latency of mesotheliomas associated with asbestos averages between 30 and 40 years it is likely that mesotheliomas related to Acre Mill will be encountered for at least the next two decades. In a recent review of several series it was found that the latent period exceeds 20 years in $96 \%$ and 15 years in $99 \%$ of cases. ${ }^{15}$ One of the Acre Mill cases had a latent period of 12 years; however, it is not possible to completely exclude an exposure from another source before his exposure at Acre Mill where he started work at the age of 36 years.

Previously, concern has been expressed about the possible danger of asbestos dust in the neighbourhood of Acre Mill ${ }^{1}$ and it was suggested that there were people who had asbestos related disease whose only possible contact with asbestos was domicile within two miles of the factory. No such cases related to the environment of Acre Mill have been verified. This is not surprising when one considers the physical location of the factory, high above Hebden Bridge on the hillside beneath the Pennine moorlands. In the presence of strong, prevailing Pennine winds it is most unlikely that pockets of asbestos would have settled within the vicinity. This is in contrast to series recording possible environmental mesotheliomas where the local topography was such that a "dust bowl" effect was likely. ${ }^{16-18}$

Thirteen out of the 17 affected women had either been directly or paraoccupationally exposed (through washing contaminated clothes) to asbestos at Acre Mill. The two cases with a history of asbestos exposure elsewhere showed raised concentrations of crocidolite within the lung tissues. Two of the remaining four cases had no history of exposure, and the normal asbestos fibre concentrations within the lungs confirmed that they were not related to asbestos. ${ }^{11}{ }^{19-20}$

Much of the research was undertaken by one of the authors (DW) in receipt of a Churchill Fellowship. We thank Mr J A Turnbull, HM Coroner for Bradford and District and his Turnbull, HM Coroner for Bradford and District and his
Coroner's Officers for their help and also $\mathrm{Dr} \mathrm{M} \mathrm{McCoubrie}$ of the Hebden Bridge Health Centre for his assistance. The analytical part of the investigation was supported by a grant from the Health and Safety Executive Commission No $1 / \mathrm{LMD} / 126270 / 88$. Finally we acknowledge the help of pathologist colleagues who readily provided pathological data and material.

1 Mann B. Pulmonary asbestosis with special reference to an epidemic at Hebden Bridge. $\mathcal{F} R$ Coll Physicians (Lond) 1978;12:297-307.

2 Anon. Acre Mill and after. Occup Health 1976;28:241-3.

3 Pooley FD, Clarke NJ. Quantitative assessment of inorganic fibrous particles in dust samples with an analytic electron microscope. Ann Occup Hyg 1979;22:253-71.

4 Jones RD, Smith DM, Thomas PG. Mesothelioma in Great Britain in 1968-83. Scand $\mathcal{f}$ Work Environ Health. 1988;14:145-52.

5 Wagner JC, Pooley FD, Berry G, Seal RME, Munday DE, Morgan J. A pathological and mineralogical study of asbestos-related deaths in the United Kingdom in 1977. Ann Occup Hyg 1982;26:423-31.

6 McDonald AD, McDonald JC, Pooley FD. Mineral fibre content of lung in mesothelial tumors in North America. Ann Occup Hyg 1982;26:417-22.

7 Gibbs AR, Stephens M, Griffiths DM, Blight BJN, Pooley FD. Fibre distribution in the lungs and pleura of subjects with asbestos related diffuse pleural fibrosis. $\mathrm{Br} \mathcal{F}$ Ind $\mathrm{Med}$ 1991;48:762-70.

8 Dawson A, Gibbs AR, Pooley FD, Griffiths DM, Hoy J. Malignant mesothelioma in women. Thorax 1993;48 269-74.

9 Jones JSP, Pooley FD, Sawle GW, Madely RJ, Smith PG, Berry $\mathrm{G}$, et al. The consequences of exposure to asbestos dust in a war-time gas mask factory. In: Wagner JC, ed. Biological effects of mineral fibres, vol 2. IARC Sci Publ Biological effects of

10 Gibbs AR. Role of asbestos and other fibres in the development of diffuse malignant mesothelioma. Thorax 1990; 45:649-54.

11 Gibbs AR, Jones JSP, Pooley FD, Griffiths DM, Wagner JC. Non-occcupational malignant mesotheliomas. In: Bignon J, Peto J, Saracci R, eds. Non-occupational exposure to mineral fibres. Lyon: International Agency for Research on Cancer, 1989;90:219-28.

12 Pooley FD, Mitha R. Fibre types, concentrations, and characteristics found in lung tissues of chrysotile-exposed cases and controls. In: Wagner JC, ed. The biological effects of chrysotile. Philadelphia: Lippincott, 1986: 1-11.

13 Wagner JC, Berry G, Skidmore JW, Timbrell V. The effects of the inhalation of asbestos in rats. Br $\mathrm{F}$ Cancer 1974;29:252.

14 Churg A, DePaoli L. Clearance of chrysotile asbestos from human lung. Exp Lung Res 1988;14:567-74. 
15 Lanphear BP, Buncher CR. Latent period for malignant mesothelioma of occupational origin. $\mathcal{F}$ Occup Med 1992; 34:718-21.

16 Wagner JC, Sleggs SA, Marchand P. Diffuse pleural mesothelioma and asbestos exposure in the North Western Cape Province. Br F Ind Med 1960:17:260-71.

17 Newhouse $M L$, Thompson H. Mesothelioma of pleura and peritoneum following exposure to asbestos in the London area. Br F Ind Med 1965;22:261-9.
18 Arblaster L, Hatton P, Renvoize EB, Schweiger MS. Leeds mesothelioma deaths 1971-87. Leeds: Leeds Western and mesothelioma deaths $1971-87$. Leeds:

19 Peterson JT, Greenberg SD, Buffler PA. Non-asbestos related malignant mesothelioma. Cancer 1984;54: related $951-60$.

20 Hirsch A, Brochard P, DeCremoux H, Erkan L, Sebatien $P$, Bignon J. Features of asbestos exposed and unexposed mesothelioma. Am $\mathcal{F}$ Ind Med 1982;3:413-22.

\section{Occupational and Environmental Medicine and the electronic age}

OEM has an Email address which is 100632.3615@compuserve.com.We welcome contact by Email, including letters to the editor. Some of our reviewers already send us their reports by Email, helping to speed up the peer review process.

We are moving towards electronic publishing and for some months now we have been asking authors to send us their revised papers on disk as well as a hard copy. I am delighted to report that nearly all our authors are managing to comply with this request; far more than for other specialist journals in the BMJ Publishing group. Oddly enough, the few authors who have not sent us a disk version of their revised papers have been almost exclusively from the United Kingdom. I would be interested in suggestions for why this might be. Perhaps United Kingdom based authors read our correspondence and instructions less assiduously? Watch for revised Instructions to Authors.

The Editor 